\title{
Foraminifera-based estimation of water depth in epicontinental seas: Badenian deposits from Glavnica Gornja (Medvednica Mt., Croatia), Central Paratethys
}

\author{
Đurđica Pezelj* and Lucija Drobnjak \\ University of Zagreb, Faculty of Science, Department of Geology, Division of Geology and Paleontology, Horvatovac 102a, 10000 Zagreb, Croatia; \\ ( ${ }^{*}$ corresponding author: djurdjica.pezelj@geol.pmf.hr)
}

Article history:

Manuscript received October 25, 2018

Revised manuscript accepted February 14, 2019 Available online May 31, 2019

Keywords: Benthic foraminifera, Palaeo-depth estimation, Badenian, North Croatian Basin, Central Paratethys

\begin{abstract}
This study presents the first attempt to estimate the palaeo-depth, and to assess the environmental conditions at the sea bottom, by means of foraminifers during the deposition of earlier Badenian deposits in the North Croatian Basin. The studied stratigraphic record, the Glavnica Gornja section is located in Mt. Medvednica, in the southwestern part of the Pannonian Basin System, and it belongs to the Upper Lagenidae Zone (Moravian substage of the Badenian). Three methods were tested to estimate the palaeo-depth; the plankton/benthos $(P / B)$ ratio indicated the lower to upper bathyal zone, the modified $\mathrm{P} / \mathrm{B}$ ratio indicated $886-987 \mathrm{~m}$ depth for the bathyal zone, whereas the Hohenegger method indicated 142-204 m depth for the outer shelf. Of the three estimates, the last is considered as best fitting the general environmental demands of the dominant and common small benthic forams. The well oxygenated sea bottom was temporarily replaced by more stressful conditions in the middle part of the studied interval, pointing to occasional variations in the organic flux.
\end{abstract}

\section{INTRODUCTION}

Paratethys, an intracontinental sea, covered a vast proportion of present-day Europe and Asia during the Miocene (RÖGL, 1998, 1999; KOVÁČ et al., 2017). The North Croatian Basin (including Medvednica Mt.; Fig. 1), as part of the Pannonian Basin System, was located in the southwestern part of the Central Paratethys (PAVELIĆ, 2001, 2005; PAVELIĆ \& KOVAČIĆ, 2018). This area had a complex geological history, because connections to the Mediterranean Sea or Neotethys and to the Eastern Paratethys realm were interrupted several times provoking changes in the sedimentary settings. The middle Miocene marine transgressive phases, especially the Badenian (Langhian, Lower Serravallian) ones, could be easily traced in sediments due to their diverse and abundant fossil content (foraminifera in particular; KOVÁČ et al.,
2007; PILLER et al., 2007). The chronostratigraphic interpretation of the Badenian stage is the subject of many debates, with numerous controversies and disagreements. Differences include two- or three-part biostratigraphic subdivision of the stage and correlation with sedimentary cycles (KOVÁČ et al., 2007, 2018; RÖGL, 1998; PILLER et al., 2007; HOHENEGGER et al., 2014; SANT et al., 2017). In the North Croatian Basin, a "layer cake" stratigraphic model was adopted and the classical small benthic foraminifera (SBF) ecozones were applied (Fig. 2): Lower and Upper Lagenidae (Moravian), Spirorutilus (Wielician) and Bulimina-Bolivina / Ammonia beccarii (Kosovian) Zones (GRILL, 1943; PAPP \& TURNOWSKY, 1953; PAPP et al., 1978; HARZHAUSER \& PILLER, 2007). These ecozones mainly represent

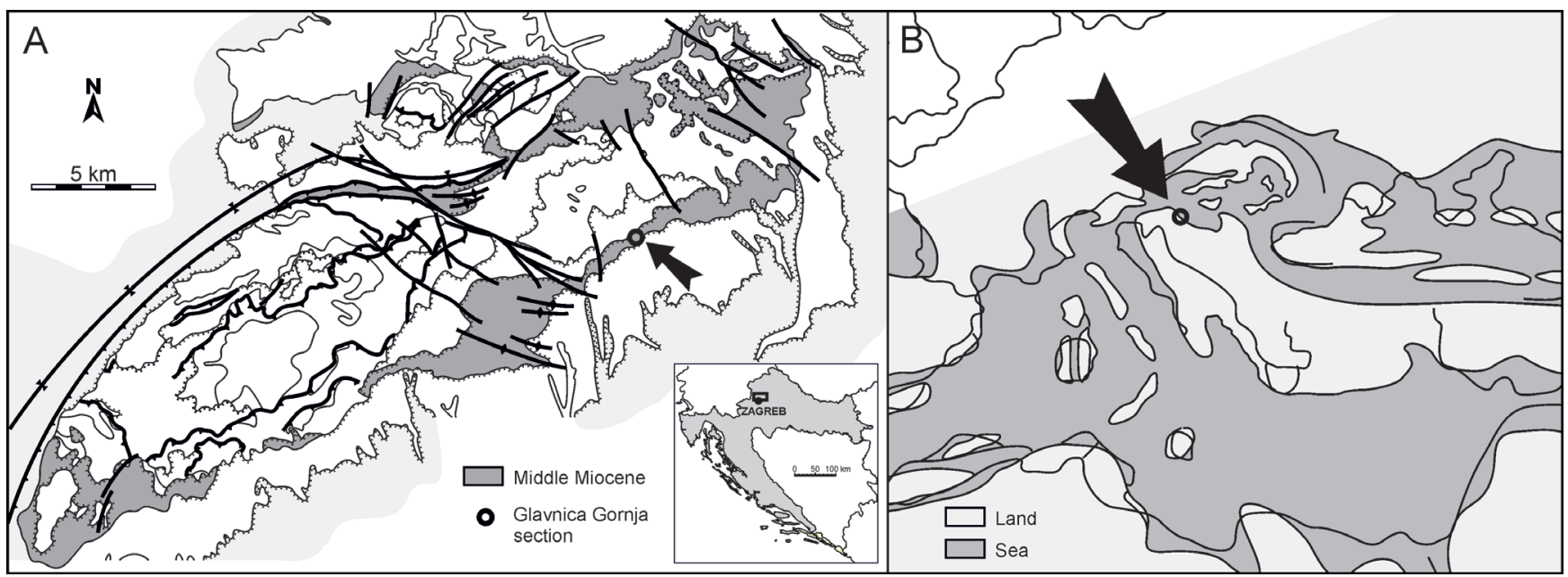

Figure 1. A. Sampling locality - Glavnica Gornja, Medvednica Mt. (ŠIKIĆ, 1995 - modified). B. Location of Medvednica Mt. within the Central Parathetys during the early Badenian (RÖGL, 1999-modified). 
the lateral shift of the sedimentary facies (ecological habitats, KOVÁČ et al., 2018).

The aim of this study is to contribute to the knowledge of environmental conditions during the Badenian (Lagenidae Biochron) in the Central Paratethys, and to describe the abundance, diversity, composition, and vertical distribution of benthic framiniferal assemblages across different productivity phases. In this paper, special attention is paid to estimation of water depth of the depositional environment. Three independent methods were used in order to decide which provides the most realistic estimate. The discrepancies in estimated palaeo-depths obtained using P/B ratio (MURRAY, 1991) or modified P/B ratio (VAN DER ZWAAN et al., 1990, 1999) method/s and the transfer functional method - Hohenegger method - based on known depth ranges of identified benthic foraminifera (HOHENEGGER, 2005) are known for middle Miocene deposits of the Central Paratethys (SPEZZAFERRI et al., 2002; HOHENEGGER, 2005; BÁLDI \& HOHENEGGER, 2008) and lower Miocene Karpatian (SCHLÖGL et al. 2011). Until now, only a few papers dealing with quantified data of Badenian SBF from the North Croatian Basin have been available, and those are mostly focused on the Upper Badenian (PEZELJ, 2006, 2007, 2013, 2017, 2018). At the Glavnica Gornja locality, analysis of the abundance and diversity of SBF assemblages from the Upper Lagenidae Zone along with foraminiferal life-habitats preferences resulted in the reconstruction of sub-environments. Thus, our present study, except for some preliminary research (PEZELJ, 2015; KOVAČIĆ et al., 2015), presents the first attempt to estimate the palaeo-depths based on quantified data and to describe the sea bottom conditions during the deposition of earlier Badenian deposits in the North Croatian basin.

\section{GEOLOGICAL SETTING AND DESCRIPTION OF THE STUDIED SECTION}

Medvednica Mt. is a $40 \mathrm{~km}$ long, southwest to the northeast trending ,,island mountain“ in the North Croatian Basin in northwestern Croatia (Fig. 1.A). The Palaeozoic, Mesozoic, and Palaeogene rocks of the mountain are surrounded by Neogene and Quaternary sediments (ŠIKIĆ K., 1995; TOMLJENOVIĆ, 2008). Two concepts are known regarding the date of the initial Miocene transgression in the North Croatian Basin. The older view holds that it occurred during the Karpatian (corresponding to the TB $2.2,3^{\text {rd }}$ order sequence) because Ottnangian freshwater deposits directly overlie Palaeozoic rocks and are overlain by Karpatian marine sediments (ŠIKIĆ et al., 1979; BASCH, 1983; ŠIKIĆ, 1995: HAJEK-TADESSE, 2009). This view is supported by some recent planktonic foraminiferal data that confirm the Karpatian age of the oldest Miocene marine sediments (PREMEC-FUČEK et al., 2017; HERNITZ KUČENJAK et al., 2018). According to the second concept (ĆORIĆ et al., 2009; PAVELIĆ \& KOVAC̆IĆ, 2018; MARTINUŠ et al., 2013; BRLEK et al., 2016, 2018) however, the beginning of initial marine transgression coincided with the early middle Badenian (corresponding to the TB 2.4, 3 rd order sequence), as proved by dating of the Cučerje tuffs (14.8 Ma; MARKOVIĆ, 2017). In this scenario, the continental phase lasted from the Ottnangian to the early Badenian, and in the early Badenian the North Croatian Basin was characterized by longlived fresh-water lacustrine deposition (Fig. 2). In either case, during the initial marine transgression the entire area of Medvednica Mt. was flooded and only the highest peak was emerged (an island surrounded by the sea). Today, the middle Miocene (Badenian and overlying Sarmatian), which forms a more or less continuous sedimentary belt around the mountain core (Fig. 1A),

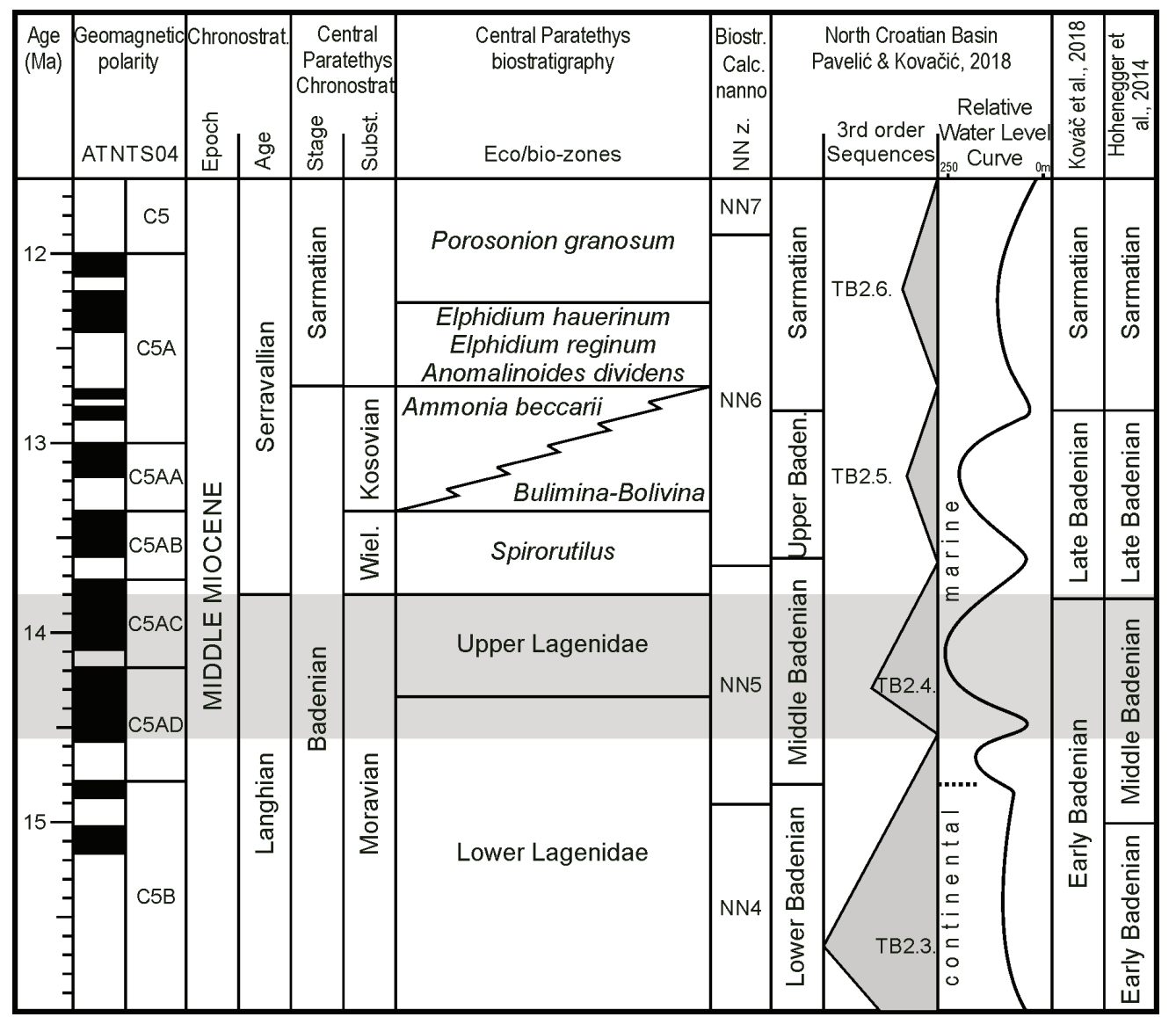

Figure 2. Middle Miocene local/regional small benthic foraminifera ecozones correlated to the regional and standard stages (modified after PEZELJ et al., 2013). 
is characterized by recognizable transgressive contact, abundance of fossils and great facies diversity due to sea-level oscillations (BASCH, 1983; ŠIKIĆ, 1995). The beginning of the late Badenian coincided with a widespread transgression over older rocks, including the pre-Neogene basement, while the BadenianSarmatian boundary coincided with partial isolation of the Paratethys Sea, causing a decrease in salinity and changes in the palaeoenvironment from marine-brackish to brackish (HARZHAUSER \& PILLER, 2007; PAVELIĆ \& KOVAČIĆ, 2018).

The Gornja Glavica section is located on the southeast slopes of the central part of Medvednica Mt. (Fig. 1A), and belongs to the so-called „Čučerje deposits" (“Čučerje development” after KOCHANSKY, 1944; KOCHANSKY-DEVIDÉ, 1957). These deposits were considered the oldest and deepest marine sediments of the Badenian stratigraphic record in Medvednica Mt. (AVANIĆ, 1997, ĆORIĆ et al., 2009, BOŠNJAK et al., 2017). The sedimentary record at Glavnica Gornja (Lat: $45^{\circ} 56^{\prime} 21^{\prime \prime}$ Lon: $16^{\circ} 08^{\prime} 23.943^{\prime \prime}$ ) outcrops along the narrow macadam road leading from Glavnica Donja village to Glavnica Gornja village, with a total thickness of $26 \mathrm{~m}$ (Fig. 3). Massive grayish to green marls with scarce fragments of bivalves and echinoids dominate the lower and upper parts of the section. In the central part, structureless massive marls and clay marls are present. Occasionally, up to $1 \mathrm{~m}$ thick marl layers occur. Six samples were taken from the section G1 to G6), from places where lithological changes were observed.

\section{METHODS}

Sediment samples (about $300 \mathrm{~g}$ each) were soaked in diluted $\mathrm{H}_{2} \mathrm{O}_{2}$ for a few hours, and then washed through a sieve system of 0.063 , $0.125,0.25$ and $0.5 \mathrm{~mm}$ size. The selected fraction for this study was $>0.063 \mathrm{~mm}$. The dried material was repeatedly split with the Reich microsplitter until a standard sample of about 300 foraminiferal tests was obtained. After determining the $\mathrm{P} / \mathrm{B}$ ratio, each sample was split again in order to obtain approximately 300 benthic foraminiferal tests for further quantitative and qualitative analysis.

Taxonomic identification of foraminifera is in accordance with PAPP et al. (1978), AGIP (1982), PAPP \& SCHMID (1985), LOEBLICH \& TAPPAN (1988 a,b), CIMERMAN \& LANGER (1991), CICHA et al. (1998), and BÁLDI (1999). Determination was corrected according to the up-to-date WORMS database (World Register of Marine Species, 2019) to exclude invalid names and synonyms. The ecological/palaeoecological preference of each benthic species was taken from MURRAY (1991, 2006), BÁLDI (2006); PEZELJ et al. (2013, 2016, including all references therein), and others referred to later in the text.

Species richness, dominant and common species were determined in each sample according to MURRAY (1991). Four diversity indices were computed using the PAST (Palaeontology Statistic) program (HAMMER et al., 2001): Fisher $\alpha$ index, Shannon-Wiener index, Dominance, and Equitability. Prior to all analyses and statistical data processing, the benthic foraminiferal assemblages were thoroughly studied to determine their autochtonity (autochtonous vs. allochtonous foraminiferal tests) and the degree of taphonomic alterations on the tests. Taphonomic analysis of foraminiferal assemblages was completed using the concept of HOLCOVÁ (1999). For this purpose, size sorting of tests, degree of test fragmentation, abrasion and corrosion were recorded. This procedure also included the recording of stratigraphic ranges and palaeoecological requirements for the identified species.

Three different methods were used to calculate the palaeodepth: the plankton/benthos ratio, the modified plankton/benthos ratio, and the Hohenegger method.

The plankton/benthos $(\mathrm{P} / \mathrm{B})$ ratio. With the increased distance from the coast, the turbidity decreases, which enables the primary production to increase and consequently leads to an increased amount of the planktonic foraminifera in the system. $\mathrm{P} / \mathrm{B}$ ratio is expressed as a percentage of planktonic foraminifera in the total foraminiferal community (MURRAY, 1991).

The modified plankton/benthos $(\mathrm{P} / \mathrm{B})$ ratio (VAN DER ZWAAN et al., 1990, 1999) is based on the fact that the availability of nutrients at the seafloor usually depends on the water depth. Deep infaunal species are excluded from the analysis because they are not directly dependent on the influx of organic matter and food on the sea floor. Based on recent research in stressful environments, VAN HINSBERGEN et al. (2005) modified the original VAN DER ZWAAN et al. (1999) formula so that the following taxa are excluded: Bolivina (except B. plicatella, B. pseudoplicata); Bulimina without ribs, Uvigerina spp. (except $U$. semiornata), Rectuvigerina, Valvulineria, Cancris, Fursenkoina, Stainfortia, Globobulimina, and Chilostomella.

The Hohenegger method. HOHENEGGER (2005) and BÁLDI \& HOHENEGGER (2008) followed a two-step procedure for estimating palaeo-depth based on the presence/absence of species: (a) information about the distributions of recent species along the depth, and (b) a transfer equation.

The bottom water oxygen content was estimated using the BFOI developed by KAIHO $(1994,1999)$. The palaeo productivity was assessed using infaunal/epifaunal ratio.

Cluster Analysis (Ward's method) and Non-metric Multidimensional Scaling (Euclidean distance dissimilarity measure) were used for the representation of relationships between samples and species. They were undertaken using the PAST (PAlaeontology STatiatic) program (HAMMER et al., 2001), and applied to all identified species of benthic foraminifera.

Foraminiferal samples are stored at the University of Zagreb, Faculty of Science, Department of Geology, Division of Geology and Paleontology.

\section{RESULTS}

The recovered microfossil assemblages are dominated by foraminifera, while rare ostracod shells and sponge spicules are present, too. Foraminiferal assemblages are characterized by wellpreserved tests, considerable species diversity, and abundance of particular species. Planktonic foraminiferal tests dominate in all studied samples, comprising more than $85 \%$ of the foraminiferal assemblages. The benthic foraminifera are in-situ, their tests are pristine, without corrosion, scraping marks or sorting by test size. Altogether, 44 benthic species were identified (Table 1): two species belong to sub-order Textulariina, one species to the sub-order Milioliina, 19 species are affiliated to the sub-order Lageniina, and 22 species belong to the Rotaliina.

Species richness ranges from 24 to 30 per sample (Fig. 3). Samples from the central part of the section (samples G3 and G4) show slightly lower values. Toward the central part of the section, values of Fisher $\alpha$ index (6.20 - 8.38), as well as the ShannonWiener index (2.50 - 2.93), decrease, and the same trend is observed with the Equitability $(0.76-0.87)$ values. In contrast, Dominance $(0.07-0.14)$ reaches the highest values in the samples from the middle of the section (Fig. 3). 
Table 1. List of identified species of benthic foraminifera, their abundance in samples and ecological/palaeoecological interpretation (O-oxic, S-suboxic, D-disoxic; E-epifauna. SI-shallow infauna, I-infauna).

\begin{tabular}{|c|c|c|c|c|c|c|c|}
\hline SPECIES / SAMPLE & G1 & G2 & G3 & G4 & G5 & G6 & \\
\hline Amphicoryna badenensis (D’ORBIGNY) & 0 & 4 & 0 & 0 & 0 & 1 & $S / I$ \\
\hline Amphicoryna hispida (D’ORBIGNY) & 1 & 0 & 0 & 0 & 0 & 1 & $S / I$ \\
\hline Anomalinoides sp. & 10 & 4 & 11 & 12 & 9 & 7 & $\mathrm{O} / \mathrm{E}$ \\
\hline Bolivina antiqua D'ORBIGNY & 0 & 0 & 0 & 2 & 0 & 0 & $D / l$ \\
\hline Bolivina dilatata REUSS & 41 & 31 & 93 & 81 & 42 & 32 & $D / I$ \\
\hline Bolivina viennensis MARKS & 26 & 18 & 35 & 54 & 30 & 41 & $D / I$ \\
\hline Bulimina elongata D'ORBIGNY & 0 & 3 & 0 & 10 & 5 & 3 & $\mathrm{D} / \mathrm{l}$ \\
\hline Bulimina striata D'ORBIGNY & 2 & 12 & 3 & 0 & 10 & 9 & $D / I$ \\
\hline Cassidulina laevigata D'ORBIGNY & 0 & 3 & 7 & 0 & 9 & 12 & $S / I$ \\
\hline Caveastomella adolphina (D'ORBIGNY) & 9 & 5 & 6 & 7 & 1 & 0 & $S / I$ \\
\hline Ceratocancris hauerii (D'ORBIGNY) & 10 & 11 & 0 & 0 & 0 & 0 & $\mathrm{~S} / \mathrm{l}$ \\
\hline Cibicidoides austriacus (D'ORBIGNY) & 21 & 32 & 16 & 14 & 31 & 28 & $\mathrm{O} / \mathrm{E}-\mathrm{SI}$ \\
\hline Cibicidoides ungerianus (D'ORBIGNY) & 52 & 43 & 35 & 21 & 45 & 30 & $\mathrm{O} / \mathrm{E}-\mathrm{SI}$ \\
\hline Chilostomella ovoidea REUSS & 7 & 0 & 0 & 8 & 1 & 0 & $\mathrm{D} / \mathrm{l}$ \\
\hline Dentalina acuta D'ORBIGNY & 1 & 0 & 0 & 0 & 0 & 2 & $\mathrm{~S} / \mathrm{l}$ \\
\hline Fursenkoina subacuta (D’ORBIGNY) & 6 & 6 & 0 & 0 & 1 & 3 & $\mathrm{D} / \mathrm{I}$ \\
\hline Glandulina ovula D'ORBIGNY & 0 & 0 & 0 & 0 & 2 & 0 & $\mathrm{~S} / \mathrm{l}$ \\
\hline Globocassidulina crassa (D'ORBIGNY) & 0 & 5 & 4 & 0 & 8 & 10 & $\mathrm{O} / \mathrm{l}$ \\
\hline Grigelis pyrulus (D'ORBIGNY) & 0 & 1 & 0 & 0 & 1 & 0 & $\mathrm{~S} / \mathrm{l}$ \\
\hline Hansenisca soldanii D'ORBIGNY & 4 & 0 & 6 & 5 & 8 & 8 & $S / E$ \\
\hline Heterolepa dutemplei D'ORBIGNY & 6 & 0 & 1 & 0 & 3 & 0 & $\mathrm{O} / \mathrm{E}$ \\
\hline Hoeglundina elegans (D'ORBIGNY) & 3 & 0 & 0 & 0 & 0 & 0 & $S / E$ \\
\hline Laevidentalina communis (D'ORBIGNY) & 0 & 0 & 0 & 3 & 2 & 1 & $S / l$ \\
\hline Laevidentalina elegans D'ORBIGNY & 0 & 3 & 5 & 2 & 7 & 0 & $S / I$ \\
\hline Lenticulina inornata (D’ORBIGNY) & 15 & 21 & 10 & 11 & 12 & 15 & $\mathrm{O} / \mathrm{SI}$ \\
\hline Lenticulina vortex (FICHTELL \& MOLL) & 0 & 2 & 1 & 0 & 0 & 2 & $\mathrm{O} / \mathrm{E}$ \\
\hline Marginulina hirsuta D'ORBIGNY & 2 & 0 & 4 & 5 & 3 & 0 & $\mathrm{~S} / \mathrm{l}$ \\
\hline Martinottiella communis (D'ORBIGNY) & 2 & 0 & 1 & 0 & 0 & 1 & $\mathrm{O} / \mathrm{E}$ \\
\hline Melonis pompilioides (FICHTELL \& MOLL) & 11 & 8 & 14 & 16 & 14 & 18 & $\mathrm{~S} / \mathrm{l}$ \\
\hline Neugeborina longiscata (D'ORBIGNY) & 9 & 5 & 10 & 6 & 0 & 0 & $\mathrm{~S} / \mathrm{I}$ \\
\hline Nonion commune (D'ORBIGNY) & 0 & 5 & 9 & 0 & 2 & 0 & $\mathrm{~S} / \mathrm{l}$ \\
\hline Planularia casis (FICHTELL \& MOLL) & 0 & 0 & 0 & 0 & 1 & 3 & $S / l$ \\
\hline Planularia dentata (KARRER) & 0 & 13 & 0 & 0 & 0 & 1 & $\mathrm{~S} / \mathrm{l}$ \\
\hline Planularia lanceolata (D'ORBIGNY) & 0 & 1 & 0 & 0 & 0 & 2 & $\mathrm{~S} / \mathrm{l}$ \\
\hline Planulina sp. & 3 & 4 & 2 & 0 & 1 & 3 & $\mathrm{O} / \mathrm{E}$ \\
\hline Pseudonodosaria brevis D'ORBIGNY & 3 & 4 & 2 & 0 & 0 & 4 & $S / l$ \\
\hline Pullenia bulloides (D'ORBIGNY) & 15 & 21 & 3 & 15 & 4 & 15 & $\mathrm{~S} / \mathrm{I}$ \\
\hline Saracenaria arcuata (D'ORBIGNY) & 0 & 6 & 0 & 4 & 0 & 0 & $S / I$ \\
\hline Spirosigmoilina tenuis (CŽJŽEK) & 2 & 7 & 0 & 1 & 4 & 8 & $\mathrm{O} / \mathrm{E}$ \\
\hline Textularia gramen D'ORBIGNY & 8 & 5 & 2 & 1 & 0 & 2 & $S / I$ \\
\hline Trifarina angulosa (WILLIAMSON) & 14 & 22 & 5 & 9 & 15 & 17 & $\mathrm{O} / \mathrm{I}$ \\
\hline Uvigerina grilli SCHMID & 2 & 0 & 0 & 2 & 1 & 0 & $D / I$ \\
\hline Uvigerina macrocarinata PAPP \& TURNOVSKI & 1 & 0 & 0 & 1 & 0 & 0 & $\mathrm{D} / \mathrm{l}$ \\
\hline Vaginulinopsis pedum (D’ORBIGNY) & 1 & 0 & 3 & 2 & 1 & 0 & $S / l$ \\
\hline summ & 308 & 293 & 301 & 303 & 299 & 304 & \\
\hline
\end{tabular}

The depth estimation based on $\mathrm{P} / \mathrm{B}$ ratio suggests an upper bathyal environment (85.2 to $92.2 \%$ of planktonic foraminifera). Based on the modified $\mathrm{P} / \mathrm{B}$ ratio the water depth was between 886 and $987 \mathrm{~m}$. According to the third applied model, the Hohhenneger method, sedimentation took place at depths ranging from 142 down to $204 \mathrm{~m}$.

Cluster analysis (Ward's method) and Non-metric Multidimensional Scaling (Euclidean distance dissimilarity measure, comparing the composition and abundances of all identified benthic foraminifera species) revealed three clusters, separated into two major groups, Group I or the Cibicidoides-Bolivina assemblage and Group II, the Bolivina assemblage, respectively (Fig. 4). Cluster 1, Cibicidoides-Bolivina assemblage, contains foraminiferal assemblages from the lower and upper parts of the section (lower samples G1 and G2 and upper samples G5 and G6) and includes 28 - 30 species. Dominant species are Cibicidoides ungerianus (average 14.9\%), Bolivina dilatata (average 12.8\%) and $B$. viennensis (average $10.2 \%$ ), whereas species $C$. austriacus (average 9.8\%) and L. inornata (average 5.5\%), while still common, are less abundant. Cluster 2, Bolivina assemblage, comprises samples from the central part of the section and consists of $24-27$ species. It is characterized by the greater abundance of Bolivina dilatata (average 29.9\%) and B. viennensis (average $15.3 \%)$. Still prominent, but less abundant within this cluster are C. ungerianus (average 9.7\%), C. austriacus (average 5.2\%) and Melonis pompilioides (average 5.2\%).

Benthic foraminiferal oxygen index values from 19.89 to 65.00 (BFOI, Fig. 3) suggest that a shift in oxygen content took place during deposition. Sediments from the lower and upper parts of the section originated during high oxic conditions. Moderate oxic conditions prevailed during sedimentation of the central part of the section, and the lowest concentration of oxygen occurred during sedimentation of sample G4, approaching lowoxic conditions. Suboxic species (comprising 35.7 to $51.1 \%$ of the total benthic assemblage) and oxic indicators (varying from 12.3 to $31.8 \%$ ) prevail in the lower and upper parts of the section, while in the middle part of the section an increase in the proportion of disoxic indicators (17.2 - 49.7\%) was observed. Within the benthic community, infaunal forms (53.4 - 77.7\%) dominate, especially in the central part of the section.

\section{STRATIGRAPHY}

In this paper, the standard biozonation scheme (Fig. 2) for the Miocene of the Central Paratethys was applied (PAPP et al., 1978; PAPP \& SCHMID, 1985; CICHA et al., 1998; PILLER et al., 2007) along with the Badenian stratigraphic correlation table proposed by HOHENEGGER, 2014; KOVÁČ, 2018 and PAVELIĆ \& KOVAČIĆ, 2018 (for North Croatian Basin). It has to be stressed that recently, for dating of the Miocene deposits of the North Croatian basin, the sub-division model by HOHENEGGER et al. (2014) was used, in which the Moravian sub-stage is correlated with the lower and middle Badenian (Fig. 2). However, this proposal is still subject to numerous discussions and is not unanimously accepted (HOLCOVÁ, 2018).

The early Badenian age of the studied samples was confirmed by the presence of Uvigerina macrocarinata PAPP \& TURNOVSKI as well as by various lageniids (Fig. 5; Table 1), some of which are index fossils for this sub-age (sensu CICHA et al., 1998), such as Planularia dentata (KARRER) and P. lanceolata (D'ORBIGNY). The occurrence of Uvigerina grilli SCHMID, Dentalina acuta D'ORBIGNY, and Pseudonodosaria brevis D'ORBIGNY is typi- 


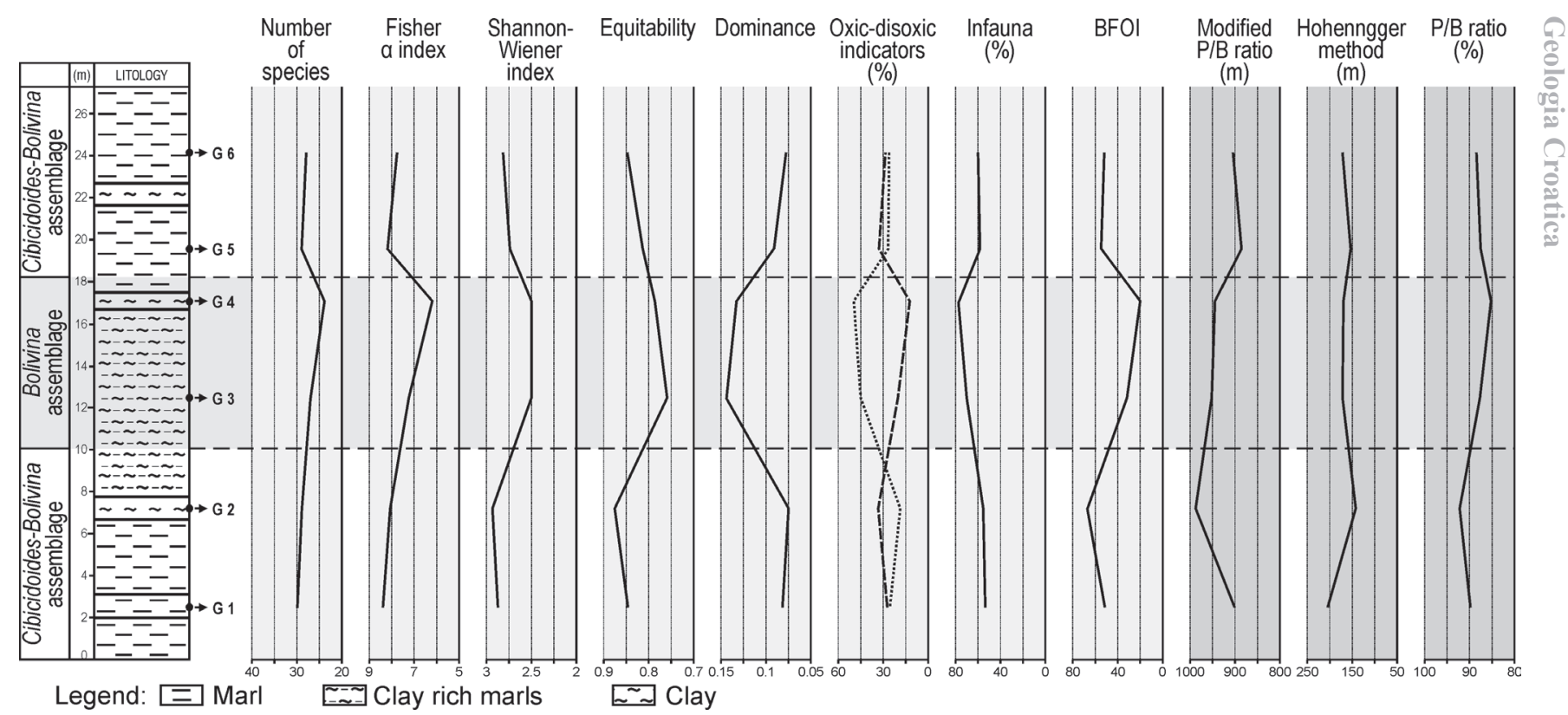

Figure 3. Glavnica Gornja section with sampling points (G), number of benthic foraminifera species, Diversity indices (Fisher a index, Shannon-Wiener index, Equitability, Dominance), oxic - disoxic indicators, epifauna/infauna ratio, BFOl, estimated depths of sedimentary basin after Hohenegger method and modified P/B ratio, and percentage of planktonic taxa.

cal for the early and middle Badenian, and Vaginulinopsis pedum (D'ORBIGNY) is typical for the Karpatian and early Badenian.

According to the standard small benthic ecobiozonation scheme (Fig. 2), our samples belong to the Lagenidae zone (Moravian, lower Badenian). Presence of the planktonic foraminifera species Orbulina suturalis BRÖNNIMANN indicate a maximum depositional age of $14.56 \mathrm{Ma}$ (the FO datum of Orbulina suturalis in the Mediterranean; IACCARINO et al., 2012). Therefore, the studied stratigraphic interval certainly correlates with the Upper Lagenidae Zone, of the middle Badenian (sensu HOHENEGGER et al., 2014; sensu PAVELIĆ \& KOVAČIĆ, 2018 for North Croatian Basin), and can be correlated with the middle Miocene sea level cycle TB 2.4 (Fig. 2).

\section{DISCUSSION}

The middle part of the Glavnica Gornja section reflects environmental changes, as the Cibicidoides-Bolivina assemblage is replaced by the Bolivina assemblage. Changes in the foraminiferal composition and species richness correspond to a decrease of diversity indices (Fisher $\alpha$ index, Shannon-Wiener index, Equitability) in the central part of the section, and a consequent increase in Dominance (Fig. 3). These changes could be related to more stressful conditions at the sea-bed. It would be reasonable to assume that they were triggered by changes in water depth.

The abundance of planktonic foraminifera in the samples varies from $85.2 \%$ to $92.2 \%$, and undoubtedly points to a good connections to the open sea. These very high values are indicative of the upper bathyal zone (MURRAY, 1991), and the highest values, above $90 \%$, for the lower bathyal zone (VALCHEV, 2003). The ratio of $\mathrm{P} / \mathrm{B}$ is a good proxy for water depth estimation, because the number of planktonic foraminifera increases with distance from the coast (GRIMSDALE \& MORKHOVEN, 1955, MURRAY, 1991). Thus, the percentage of planktonic foraminifera within the fossil assemblages should indicate the water depth, but this is not a linear function (VAN HINSBERGEN et al., 2005). Sometimes a high percentage of planktonic foraminifera can be present in shallow water environments as a consquence of predominating onshore winds (VELLA, 1962). The $\mathrm{P} / \mathrm{B}$ ratio is not affected solely by the water depths; selective dissolution of planktonic tests and changes in the amount of dissolved oxygen at the sea-bed may also control the P/B ratio (SEN-GUPTA \& MACHAN-CASTILLO, 1993; JORISSEN et al., 1995,
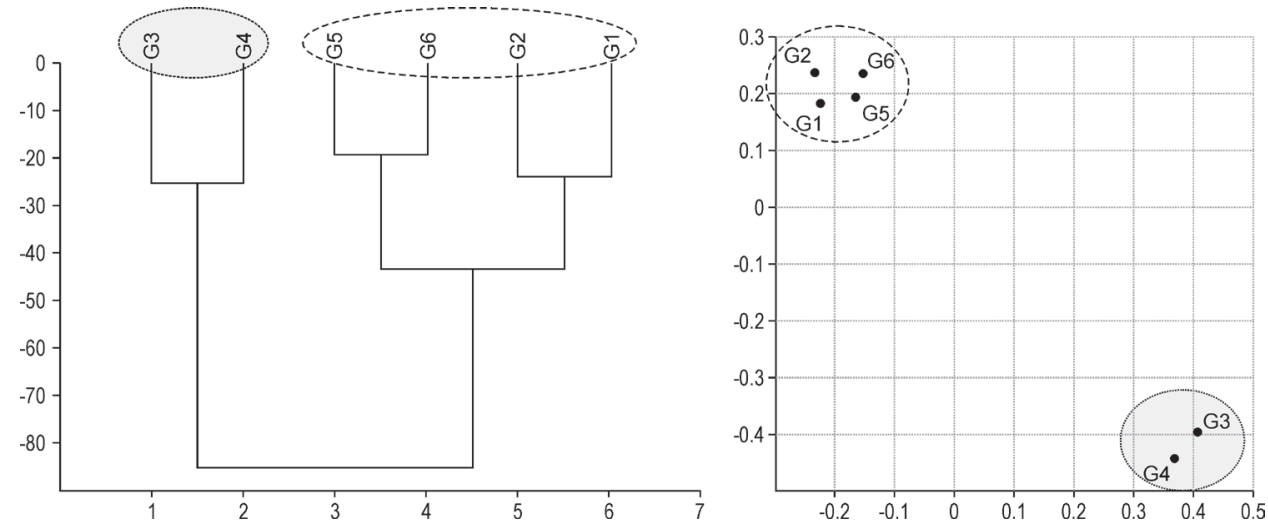

Figure 4. Cluster Analysis (Ward's method) and Non-metric Multidimensional Scaling (Euclidean). 


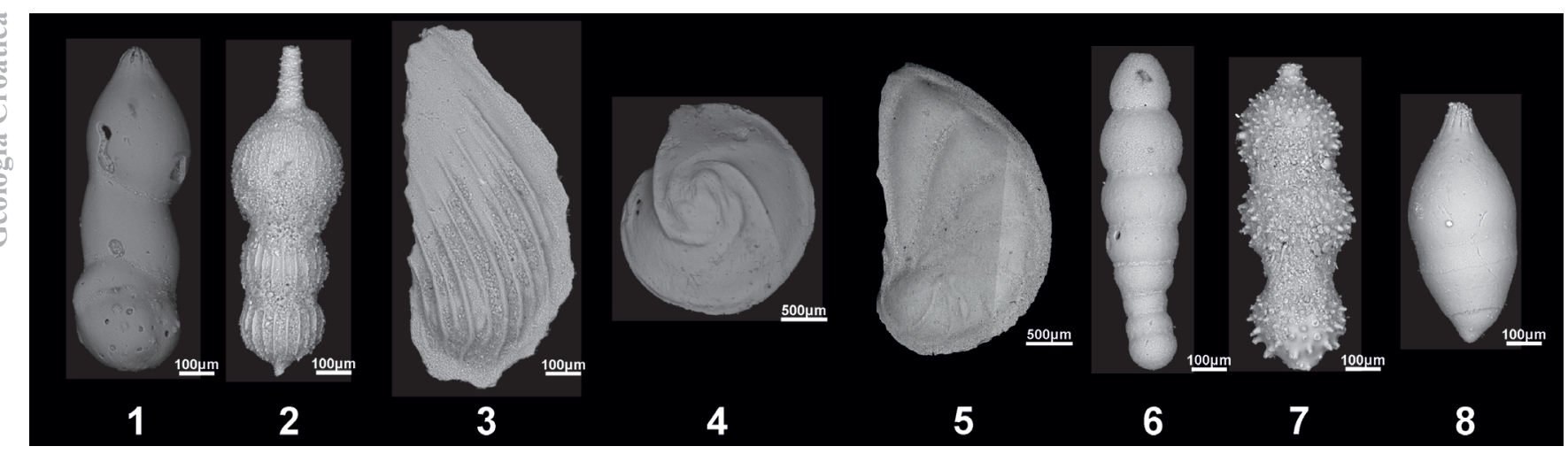

Figure 5. Selected benthic foraminiferal species from Glavnica Gornja. 1. Vaginulinopsis pedum (D'ORBIGNY), sample G3: 2. Amphicoryna badenensis (D'ORBIGNY). Sample G2; 3. Planularia lanceolata (D'ORBIGNY), sample G6; 4. Lenticulina vortex (FICHTELL \& MOLL), sample G6; 5. Planularia dentata (KARRER), sample G2; 6. Pseudonodosaria brevis D'ORBIGNY, sample G2; 7. Marginulina hirsuta D’ORBIGNY, sample G5; 8. Glandulina ovula D’ORBIGNY, sample G5.

KOUWENOVEN et al., 2003). It is known how reduced oxygenation at the seabed affects the quantity and quality of available food (nutrient composition) and causes an increase in the proportion of organic matter in the sediment (GOODAY et al., 2000). This leads to a drop in the abundance of less tolerant species, especially those that are epifaunal (DE STIGTER et al., 1996). In contrast, species adapted to oxygen deficiency thrive because of an increase in nutrients (JORISSEN, 1999; DUIJNSTEE et al., 2004). Under oxygen-deficient (unfavourable) conditions, deep infaunal species may dominate and for this reason the modified P/B ratio (VAN DER ZWAAN et al., 1990, 1999) method excludes them. The calculated water depth for Glavnica Gornja samples, based on the modified $\mathrm{P} / \mathrm{B}$ ratio, is between 886 to $987 \mathrm{~m}$, which corresponds to the middle bathyal zone of the Mediterranean continental slope (EINIG, 1997). Such great depths, however, do not fit with the depth range distribution of the identified benthic foraminifera, because their depth ranges coincide (overlap) with the outer shelf range. The absence or low abundance of typical bathyal and deeper water taxa (in particular Uvigerina and agglutinated forms) certainly indicates shallower conditions than those suggested by the modified $\mathrm{P} / \mathrm{B}$ ratio.

The Hohenegger method for estimation of palaeo-depth (HOHENEGGER, 2005, BÁLDI \& HOHENEGGER, 2008) is based on the depth range of recent species of benthic foraminifera. In any case, it should be emphasized that it is impossible to construct a general scheme of depth zoning that would be applicable to all areas of the world, because the species depth range depends on local physico-chemical and biological conditions. Any particular species will be most abundant where the optimum ecological conditions are developed for them (MURRAY, 2006). Therefore, in the palaeoecological reconstruction, the ecological demand of the dominant and common species should be consiedered in the first place. At the Glavnica Gornja locality, palaeo-depths obtained by the Hohenegger method range from 142 to $204 \mathrm{~m}$ and indicate the outer shelf, which is far more realistic than the results of the P/B and modified P/B methods. We can speculate that the high percentage of planktonic foraminifera in our samples suggests the predominance of onshore winds or increased primary production.

Regardless of the differences in the obtained water depth values (Fig. 3) it is evident that all three methods show only minor oscillations in the depth of the depositional environment. The change in foraminiferal assemblages in the central part of the section thus cannot be attributed to changes in the palaeo-depth.
What does the small benthic foraminifera of the Glavnica Gornja section suggest about the amount of oxygen at the sea bed? The values of BFOI (Fig. 3) indicate that highly oxic conditions prevailed during sedimentation of the upper and lower parts of the section. Good water circulation throughout the water column ensured oxygenation of sea-bottom water, and suggests that the local climate could be certainly warm (increased evaporation over precipitation and river influx to the basin). Oxic indicative species, such as $C$. ungerianus, $C$. austriacus and L. inornata (Table 1) were common within the Cibicidoides-Bolivina assemblage. In the central part of the section (Bolivina assemblage) a reduction in oxygen content occurred. Moderate to almost low oxic conditions (sample $\mathrm{G} 4$ ) are defined based on BFOI indices. Also, the apparent increase in the proportion of disoxic species and infaunal forms (Fig. 3) (B. dilatata, B. viennensis and B. elongata) suggests that there could be a change in the quantity and quality of available food. It is possible to assume that organic matter and nutrients were brought into the sedimentation system either due to increased primary production or to increased terrigenous influx.

The results of analysis of small benthic foraminiferal assemblages from this study generally coincide with the results obtained from other Badenian sites of the Central Parathetys (KOVÁČOVÁ \& HUDÁČKOVÁ, 2005; BÁLDI \& HOHENEGGER, 2008; BÁLDI 2006; KOPECKA 2012; PERYT 2013; PEZELJ 2013; DOLÁKOVÁ et al., 2014, 2015; RYBAR et al., 2015; NEHYBA et al., 2016). In the early Badenian, an antiestuarine circulation pattern with a weakly stratified or non-stratified water column and well-ventilated sea bottom developed, supporting a relatively diverse assemblage of benthic foraminifera (BÁLDI, 2006; KOVÁČ et al., 2007, KOVÁČ et al., 2017, 2018). At the Glavnica Gornja locality, a more stable, deep water environment (ca. $200 \mathrm{~m}$ ) was established after the TB 2.4 transgression. It was characterized by occasional episodes of minor oscillations in water depth and fluctuations in the intensity of primary production or terrigenous influx.

\section{CONCLUSIONS}

Diverse and abundant assemblages of small benthic foraminifera (44 species) thrived during the Badenian (Upper Lagenidae biochron) in the area of the Glavnica Gornja section (Medvednica Mt.). The calculation of water depth by different methods highlighted that the Hohenegger method produced the most plausible results (outer shelf) and thus it can be considered a reliable method for estimating water depth in epicontinental seas such as 
the Central Paratethys. High oxic conditions (Cibicidoides-Bolivina assemblage) prevailed at the sea-bed, whereas the central part of the section (Bolivina assemblage) reflects moderate to nearly low oxic conditions. The succession of foraminiferal assemblages illustrates the interplay between oxygen and food availability, where a decrease of oxygen correlates to an increase in organic matter and nutrients. Stressed conditions in the central part of the section were also confirmed by the decrease in diversity and increasing importance of dominance within the benthic foraminiferal assemblage as well as a significant increase in the proportion of disoxic and infaunal forms. The most important factors influencing the distribution of benthic foraminifera in the studied section are fluctuations in the amount of oxygen available at the sea bottom and/or flux of organic matter and nutrients into the environment, while minor oscillations in water depth are not reflected in the changes of the foraminiferal assemblages.

\section{ACKNOWLEDGEMENT}

Many thanks go to N. HUDÁČKOVÁ and an anonymous reviewer for critical suggestions helping to improve the manuscript. The authors are grateful to an anonymous Associate Editor and V. ĆOSOVIĆ for helpful comments and suggestions.

\section{REFERENCES}

AGIP s.p.A. (1982): Foraminiferi Padani (Terziaro e Quateriniario).- Carlo Saccardo \& Figli, Milano, $52 \mathrm{p}$.

AVANIĆ, R. (1997): Analiza facijesa srednjeg miocena jugoistočnog dijela Medvednice [Middle Miocene facies analysis of of southeastern part of Medvednica Mt. - in Croatian, with an English Abstract].- Unpubl. Master Thesis, Faculty of Science, University of Zagreb, Zagreb, $54 \mathrm{p}$.

BÁLDI, K. \& HOHENEGGER, J. (2008): Palaeoecology of benthic foraminifera of the Baden - Sooss section (Badenian, Middle Miocene, Vienna Basin, Austria).- Geol. Carpath., 59/5, 411-424.

BÁLDI, K. (2006): Pleoceanography and climate of the Badenian (Middle Miocene, 16.4-13.0 Ma) in the Central Paratethys based on foraminifera and stable isotope ( $818 \mathrm{O}$ and $\delta 13 \mathrm{C}$ ) evidence.- Int. J. Earth Sci. (Geol. Rundsch.), 95, 119-142.

BÁLDI, K. (1999): Taxonomic notes on benthic foraminifera from SW-Hungary, Middle Miocene (Badenian) Paratethys.- Acta Geol. Hungar., 42/2, 193-236.

BASCH, O. (1983): Osnovna geološka karta SFRJ, 1:100.000, Tumač za list Ivanić Grad L33-81 [Basic Geological Map of SFRY 1:100000, Geology of the Ivanić Grad sheet - in Croatian].- Inst. geol. istraž., Zagreb, Savezni geološki zavod, Beograd, 66 p.

BOŠNJAK, M., SREMAC, J., VRSALJKO, D., AŠČIĆ, Š. \& BOSAK, L. (2017). The Miocene "Pteropod event" in the SW part of the Central Paratethys (Medvednica Mt., Northern Croatia).- Geol. Carpath., 68/4, 329-349.

BRLEK, M., IVEŠA, L., BRČIĆ, V., SANTOS, A., ĆORIĆ, S., MILOŠEVIĆ, M., AVANIĆ, R., DEVESCOVI, M., PEZELJ, Đ., MIŠUR, I. \& MIKNIĆ, M. (2018): Rocky-shore unconformities marking the base of Badenian (Middle Miocene) transgressions on Mt. Medvednica basement (North Croatian Basin, Central Paratethys).Facies, 64/3, 1-25. doi: 10.1007/s10347-018-0537-0.

BRLEK, M., ŠPIŠIĆ, M., BRČIĆ, V., MIŠUR, I., KUREČIĆ, T., MIKNIĆ, M., AVANIĆ, R., VRSALJKO, D. \& SLOVENEC, Da. (2016): Mid-Miocene (Badenian) transgression on Mesozoic basement rocks in the Mt. Medvednica area of northern Croatia.- Facies, 62/3, 1-18. doi: 10.1007/s10347-016-0470-Z

CICHA, I., RÖGL, F., RUPP, C. \& CTYROKA, J. (1998): Oligocene-Miocene foraminifera of the Central Paratethys.-Abh. senckenberg. naturforsch. Ges., 549, 1-325.

CIMERMAN, F. \& LANGER, M.R. (1991): Mediterranean Foraminifera.- Prir. istraž. Slov. akad. znan. umjetn., 30, 1-118

ĆORIĆ, S., PAVELIĆ, D., RÖGL, F., MANDIC, O., VRABAC, S., AVANIĆ, R., JERKOVIĆ, L. \& VRANJKOVIC, A. (2009): Revised Middle Miocene datum for initial marine flooding of North Croatian Basins (Pannonian Basin System, Central Paratethys).- Geol. Croat., 62/1, 31-43. doi: 10.4154/GC.2009.03

DE STIGTER, H.C., JORISSEN, F.J. \& VAN DER ZWAAN, G.J. (1996): Modelling the population dynamics of benthic foraminiferal communities under seasonally fluctuating bottom water oxygen concentrations.- Geol. Ultraiect., 144, 179-208.

DOLÁKOVÁ, N., HOLCOVÁ, K., NEHYBA, S., HLADILOVÁ, Š., BRZOBOHATÝ, R., ZÁGORŠEK, K., HRABOVSKÝ, J., SEKO, M. \& UTESCHER, T. (2014): The Badenian parastratotype at Židlochovice from the perspective of the multiproxy study.- Neues Jahrb. Geol. P.-A., 271/2, 169-201.

DUIJNSTEE, I.A.P., DE LUGT, I., VONK NOORDEGRAAF, H. \& VAN DER ZWAAN, B. (2004): Temporal variability of foraminiferal densities in the northern Adriatic Sea.- Mar. Micropalaeontol., 50, 125-148. doi: 10.1016/S0377-8398(03) 00069-0
EINIG, C.C. (1997). Bathyal zones of the Mediterranean continental slope: An attempt.Publ. Espec. Inst. Esp. Oceanogr., 23, 23-33.

GOODAY, A.J., BERNHARD, J.M., LEVIN, L.A. \& SUHR, S.B. (2000): Foraminifera in the Arabian Sea oxygen minimum zone and other oxygen-deficient settings: taxonomic composition, diversity, and relation to metazoan faunas.- Deep-Sea Res. II, 47, 25-54. doi: 10.1016/S0967-0645(99)00099-5

GRILL, R. (1941): Stratigraphische Untersuchungen mit Hilfe von Mikrofaunen im Wiener Becken und den benachbarten Molasse-Anteilen.- Oel. U. Köhle Berlin, 595-602.

GRIMSDALE, T.F. \& MORKHOVEN, F.P.C.M. (1955): The ratio between pelagic and benthonic foraminifera as a means of estimating depth of deposition of sedimentary rocks.- Proc. World petroleum Cong. 4th, Rome, 4/1, 473-491.

HAJEK-TADESSE, V., BELAK, M., SREMAC, J., VRSALJKO, D. \& WACHA, L. (2009): Early Miocene ostracods from the Sadovi section (Mt Pozeska gora, Croatia).- Geol. Carpath., 60, 251-262. doi: 10.2478/v10096-009-0017-0.

HAMMER, O., HARPER, D.A.T. \& RYAN, P.D. (2001): PAST: palaeontological statistics software package for education and data analysis.- Palaeol. Electron., 4/1 (9pp. ://palaeoelectronica.org/2001_1/past/issue1_01.htm).

HARZHAUSER, M. \& PILLER, W.E. (2007): Benchmark data of a changing sea-palaeogeography, palaeobiogeography and events in the Central Paratethys during the Miocene-- Palaeogeogr. Palaeoclimatol. Palaeoecol., 253/1-2, 8-31.

HERNITZ KUČENJAK, M., PREMEC FUĆEK, V., KRIZMANIĆ, K., TADEJ, J., ZLATAR, S. \& MATOŠEVIĆ, M. (2018): Karpatian and Badenian transgression in Croatian part of the pannonian Basin System (biostratigraphy and palaeoenvironments).In: FORAMS 2018 International Symposium on Foraminifera. Foraminifera in a Changing World. Temporary Abstracts Collection, Edinburgh.

HOHENEGGER, J., ĆORIĆ, S. \& WAGREICH, M. (2014): Timing of the Middle miocene Badenian stage of the central Paratethys.- Geol. Carpath., 65/1, 55-66. doi: 10.2478/geoca-2014-0004

HOHENEGGER, J. (2005): Estimation of environmental palaeogradient values based on presence/absence data: a case study using benthic foraminifera for palaeodepth estimation.- Palaeogeogr. Palaeoclimatol. Palaeoecol., 217, 115-130.

HOLCOVÁ, K., DOLÁKOVÁ, N., NEHYBA, S. \& VACEK, F. (2018): Timing of Langhian bioevents in the Carpathian Foredeep and northern Pannonian Basin in relation to oceanographic, tectonic and climatic processes.- Geol. Q., 62/1, 3-17. doi: 10.7306/gq.1399

HOLCOVÁ, K., BRZOBOHATÝ, R., KOPECKÁ, J. \& NEHYBA, S. (2015): Reconstruction of the unusual Middle Miocene (Badenian) palaeoenvironment of the Carpathian Foredeep (Lomnice/Tišnov denudational relict, Czech Republic).- Geol. Q., 59/4, 654-678.

HOLCOVÁ, K. (1999): Postmortem transport and resedimentation of foraminiferal tests: relations to cyclical changes of foraminiferal assemblages.- Palaeogeogr. Palaeoclimatol. Palaeoecol., 145/1-3, 157-182. doi: 10.1016/S0031-0182(98)00100-X

IACCARINO, S.M., DI STEFANO, A., FORESI, L.M., TURCO, E., BALDASSINI, N., CASCELLA, A., DA PRATO, S., FERRARO, L., GENNARI, R., HILGEN F.J., LIRER, F., MANISCALCO, R., MAZZEI, R., RIFORGIATO, F., RUSSO, B., SAGNOTTI, L., SALVATORINI, G., SPERANZA, F. \& VERDUCCI, M. (2012): High-resolution intergrated stratigraphy of the upper Burdigalian-lower Langhian in the Mediterranean: the Langhian historical stratotype and new candidate sections for defining its GSSP.- Stratigraphy, 8, 195-215.

JORISSEN, F.J. (1999): Benthic foraminiferal successions across Late Quaternary Mediterranean sapropels.-Mar. Geol., 153, 91-101. doi: 10.1016/S0025-3227 (98)000887

JORISSEN, F.J., DE STIGTER, H.C. \& WIDMARK, J.G.V. (1995): A conceptual model explaining benthic foraminiferal microhabitats.- Mar. Micropalaeontol., 26, 3-15. doi: 10.1016/0377-8398(95)00047-X

KAIHO, K. (1999): Effect of organic carbon flux and dissolved oxygen on the benthic foraminiferal oxygen index (BFOI).- Mar. Micropalaeontol., 37, 67-76. doi: 10.1016/ S0377-8398(99)00008-0

KAIHO, K. (1994): Benthic foraminiferal dissolved-oxygen index and dissolved-oxygen levels in the modern ocean.- Geology, 22, 719-722. doi: 10.1130/0091-7613(1994) 022\%3C0719:BFDOIA\%3E2.3.CO;2

KOCHANSKY-DEVIDÉ, V. (1957): O fauni miocena i o tortonskom "šliru” Medvednice (Zagrebačka gora) [About Miocene fauna and Tortonian "Schlier" of Medvednica Mt. (Zagrebačka Gora) - in Croatian].- Geol. vjesnik, 10, 39-50.

KOCHANSKY, V. (1944): Fauna marinskog Miocena južnog pobočja Medvednice (Zagrebačke gore) [Marine Miocene fauna from southern slopes of Medvednica Mt, (Zagrebačka Gora)- in Croatian].- Vjestnik hrv.-drž. geol. zavoda i Hrv. drž. geol. muzeja, 2/3, 171-280.

KOPECKÁ, J. (2012): Foraminifera as environmental proxies of the Middle miocene (Early Badenian) sediments of the Central depression (Central Paratethys, Moravian part of the carpathian foredeep).- Bull. Geosc., 87/3, 431-442. doi: 10.3140/bull.geosci.1299

KOUWENHOVEN, T.J., HILGEN, F.J. \& VAN DER ZWAAN, G.J. (2003): Late Tortonian - early Messinian stepwise disruption of the Mediterranean - Atlantic connections: constrains from benthic foraminiferal and geochemical data.- Palaeogeogr. Palaeoclimatol. Palaeoecol., 198, 303-319. doi: 10.1016/S0031-0182(03)00472-3 
KOVÁČ, M., HALÁSOVÁ, E., HUDÁČKOVÁ, N., HOLCOVÁ, K., HYŽNÝ, M., JAMRICH, M. \& RUMAN, A. (2018): Towards better correlation of the Central Paratethys regional time scale with the standard geological time scale of the Miocene Epoch.- Geol. Carpath., 69/3, 283-300.

KOVÁČ, M., HUDÁČKOVÁ, N., HALÁSOVÁ, E., KOVÁČOVÁ, M., HOLCOVÁ, K., OSZCZYPKO-CLOWES, M., BÁLDI, K., LESS, G., NAGYMAROSY, A., RUMAN, A., KLUČIAR, T. \& JAMRICH, M. (2017): The Central Paratethys palaeoceanography: a water circulation model based on microfossil proxies, climate, and changes of depositional environment.- Acta Geol. Slov., 9/2, 75-114.

KOVÁČ, M., ANDREYEVA-GRIGOROVICH, A., BAJRAKTAREVIĆ, Z., BRZOBOHATŶ, FILIPESCU, S., FODOR, L., HARZHAUSER, M., NAGYMAROSY, A., OSZCZYPKO, N., PAVELIĆ, D., RÖGL, F., SAFTIĆ, B., SLIVA, L. \& STUDENCKA, B. (2007): Badenian evolution of the Central Paratethys Sea: palaeogeography, climate and eustatic sea-level changes.- Geol. Carpath., 58/6, 579-606.

KOVAČIĆ, M., MARKOVIĆ, F., ĆORIĆ, S., PEZELJ, Đ., HERNITZ-KUČENJAK, M., PREMEC-FUĆEK, V. \& BALEN, D. (2015): Geological section Njězić - Badenian marine sediments with tuff.- In: HORVAT, M. \& GALOVIĆ, L. (eds.): Excursion Guide-book. 5th Croatian Geological Congress, Osijek. Croatian Geological Survey, Zagreb, 44-47.

KOVÁČOVÁ, P. \& HUDÁČKOVÁ, N. (2005): Lower/Middle Badenian foraminiferal associations from the Vienna Basin (Slovak part) and Carpathian Foredeep: Biostratigraphy and palaeoecology. - Slovak Geol. Magazine, 11/4, 233-248.

LOEBLICH, A.R. \& TAPPAN, H. (1988a): Foraminiferal genera and their classification.Van Nostrand Reinhold, New York, 970 p. doi: 10.1007/978-1-4899-5760-3

LOEBLICH, A.R. \& TAPPAN, H. (1988b): Foraminiferal genera and their classification. Plates.- Van Nostrand Reinhold, New York, 1059 p.

MARKOVIĆ, F. (2017): Miocenski tufovi Sjevrnohrvatskog bazena [Miocene tuffs of the North Croatian Basin - in Croatian, with an English Abstract].- Unpubl. PhD Thesis, Faculty of Science, University of Zagreb, $170 \mathrm{p}$.

MARTINUŠ, M., FIO, K., PIKELJ, K. \& AŠČIĆ, Š. (2013): Miocene warm-temperate carbonates of Central Paratethys (Mt. Zrinska Gora, Croatia): palaeoenvironmental reconstruction based on bryozoans, coralline red algae, foraminifera, and calcareous nannoplankton.- Facies, 59, 481-504. doi: 10.1007/s10347-012-0327-z

MURRAY, J.W. (2006): Ecology and Applications of Benthic Foraminifera. Cambridge - University Press, Cambridge, 438 p. doi: 10.1017/CBO9780511535529

MURRAY, J.W. (1991): Ecology and Palaeoecology of Benthic foraminifera. Longman - Scientific and Tehnical, Harlow, Essex, 397 p.

NEHYBA, S., HOLCOVÁ, K., GEDL, P. \& DOLÁKOVÁ, N. (2016): The Lower Badenian transgressive-regressive cycles-a case study from Oslavany (Carpathian Foredeep, Czech Republic).- Neues Jahrb. Geol. P.-A., 279 /2, 209-238.

PAPP, A. \& SCHMID, M.E. (1985): The Fossil foraminifera of the Tertiary basin of Vienna. Die fossilen foraminiferen des Tertiaren Bekens von Wien.- Abh. Geologisch. Bundesanst., Band 37, 1-311.

PAPP, A. \& CICHA, I. (1978): 4. Definition der Zeiteinheit M - Badenien.- In: PAPP, A., CICHA, I., SENEŠ, J. \& STEININGER, F. (eds.): M4-Badenien (Moravien, Wielicien, Kosovien). Chronostratigraphie und Neostratotypen, Miozän der Zentralen Paratethys. 6. VEDA, Bratislava, 47-48.

PAPP, A. \& TURNOVSKY, K. (1953): Die Entwicklung der Uvigerinen im Vindobon (Helvet und Torton) des Wiener Beckens.- Jahrb. Geol. Bund., Wien 96, 117-142.

PAPP, A., CICHA, I. \& ČTYROKÁ, J. (1978): Foraminifera.- In: PAPP, A., CICHA, I., SENEŠ, J. \& STEININGER, F. (eds.): Chronostratigraphie und neostratotypen miozän der Zentralen Parathetys. Badenian, Verlag der Slowak. Akad. der Wissen., Bratislava, 263-325.

PAVELIĆ, D. (2005): Cyclicity in the evolution of the Neogene North Croatian basin (Pannonian Basin System).- In: MABESOONE, J.M. \& NEUMANN, V.H. (eds.): Cyclic Development of Sedimentary Basins. Dev. Sedim., Elsevier, 57, 273-283. doi: 10.1016/S0070-4571(05)80011-1

PAVELIĆ, D. (2001): Tectonostratigraphic model for the North Croatian and North Bosnian sector of the Miocene Pannonian Basin System.- Basin Res. 13, 359-376. doi: 10.1046/j.0950 -091x.2001.00155.

PAVELIĆ, D. \& KOVAČIĆ, M. (2018): Sedimentology and stratigraphy of the Neogene rift-type North Croatian Basin (Pannonian Basin System, Croatia): A review.- Mar. Petrol. Geol., 91, 455-469. doi: 10.1016/j.marpetgeo.2018.01.026

PERYT, D. (2013): Foraminiferal record of the Middle Miocene climate transition prior to the Badenian salinity crisis in the Polish Carpathian Foredeep Basin (Central Paratethys).- Geol. Q., 57/1, 141-164. doi: 10.7306/gq.1080

PEZELJ, D. (2018): Evidence of seasonality in Middle Miocene Central Paratethys shallow marine shelf - recorded by benthic foraminifera.- In: FORAMS 2018 International Symposium on Foraminifera, Foraminifera in a Changing World. Temporary Abstracts Collection, Edinburgh.

PEZELJ, Đ., SREMAC, J., KOVAČIĆ, M., ALAGIĆ, S. \& KAMPIĆ, Š. (2017): Middle Miocene Badenian-Sarmatian Sedimentary Sequence in the Area of Donje Orešje/ Medvednica Mt., Croatia.-In: HORVAT, M. \& WACHA, L. (eds.): 7th International Workshop, Neogene of Central and South-Eastern Europe, Abstracts Book, May 2017, Velika, Croatia, 46-47.
PEZELJ, Đ., SREMAC, J. \& BERMANEC, V. (2016): Shallow-water benthic foraminiferal assemblages and their response to the palaeoenvironmental changes-example from the Middle Miocene of Medvednica Mt. (Croatia, Central Paratethys).- Geol. Carpath., 67/4, 329-345. doi: 10.1515/geoca-2016-0021

PEZELJ, D. (2015): Donjobadenske bentičke foraminifere lokaliteta Glavnica gornja [Early Badenian benthic foraminifera from Glavnica Gornja locality - in Croatian]. - In: MAUCH LENARDIĆ, J., HERNITZ KUČENJAK, M., PREMEC FUĆEK, V. \& SREMAC, J. (eds.): International scientific meeting 100th birth anniversary of Vanda Kochansky-Devidé, full member of Academy, Zagreb, HAZU, 72-73.

PEZELJ, D., MANDIC, O. \& CORIC, S. (2013): Palaeoenvironmental dynamics in the southern Pannonian Basin during initial Middle Miocene marine flooding.- Geol. Carpath., 64/1, 81-100.

PEZELJ, Đ., SREMAC, J. \& SOKAČ, A. (2007): Palaeoecology of the Late Badenian foraminifera and ostracoda from the SW Central Paratethys (Medvednica Mt., Croatia).- Geol. Croat., 60/2, 139-150.

PEZELJ, Đ. (2006): Palaeoekološki odnosi badena i sarmata, planina Medvednica [Palaeoecological relationship beetwen Badenian and Sarmatian deposits from the Medvednica Mt. - in Croatian, with an English Abstract].- Unpubl. PhD Thesis, Faculty of Science, University of Zagreb, $132 \mathrm{p}$.

PILLER, W.E., HARZHAUSER, M. \& MANDIC, O. (2007): Miocene Central Paratethys stratigraphy - current status and future directions.- Stratigraphy, 4, 151-168.

PREMEC FUĆEK, V., HERNITZ KUČENJAK, M., KRIZMANIĆ, K., TADEJ, J. \& ZLATAR, S. (2017): Controversies on Karpatian and Badenian transgressions in Croatian part of the Pannonian Basin System (biostratigraphy and palaeoenvironments).- In: HORVAT, M. \& WACHA, L. (eds.): 7th International Workshop, Neogene of Central and South-Eastern Europe, Abstracts Book, May 2017, Velika, Croatia, 50-51.

RÖGL, F. (1999): Mediterranean and Paratethys. Facts and hypotheses of an Oligocene to Miocene palaeogeography (short overview).- Geol. Carpathica, 50/4, 339-349.

RÖGL, F. (1998): Palaeographic consideration for Mediterranean and Paratethys seaways (Oligocene to Miocene).-Ann. Naturhist. Mus., 99A, 279-310.

RYBÁR, S., HALÁSOVÁ, E., HUDÁČKOVÁ, N., KOVÁČ, M., KOVÁČOVÁ, M., ŠARINOVÁ, K. \& ŠUJAN, M. (2015): Biostratigraphy, sedimentology and palaeoenvironments of the northern Danube Basin: Ratkovce 1 well case study.- Geol. Carpath., 66/1, 51-67.

SANT, K., V. PALCU, D., MANDIC, O. \& KRIJGSMAN, W. (2017): Changing seas in the Early-Middle Miocene of Central Europe: a Mediterranean approach to Paratethyan stratigraphy.- Terra Nova, 29/5, 273-281.

SEN GUPTA, B.K. \& MACHAIN-CASTILLO, M.L. (1993): Benthic foraminifera in oxygen poor habits.- Mar. Micropalaeontol., 20/1, 183-201.

SCHLÖGL, J., CHIRAT, R., BALTER, V., JOACHIMSKI, M., HUDÁČKOVÁ, N. \& QUILLÉVÉRÉ, F. (2011): Aturia from the Miocene Paratethys: An exceptional window on nautilid habitat and lifestyle.- Palaeogeogr., Palaeoclimatol., Palaeoecol., 308/3, 330-338. doi: 10.1016/j.palaeo.2011.05.037

SPEZZAFERRI, S., CORIC, S., HOHENEGGER, J. \& RÖGL, F. (2002): Basin-scale palaeobiogeography and palaeoecology: an example from Karpatian (Latest Burdigalian) benthic and planktonic foraminifera and calcareous nannofossils from the Central Paratethys.- Geobios, 24, 241-256.

ŠIKIĆ, K. (1995): Prikaz geološke građe Medvednice (Geological composition of the Medvednica Mt. - in Croatian).- In: ŠIKIĆ, K. (ed.): Geološki vodič Medvednice. Inst. Geol. Istraž., Zagreb, 7-30.

ŠIKIĆ, K., BASCH, O. \& ŠIMUNIĆ, A. (1978): Osnovna geološka karta SFRJ 1:100.000. Tumač za list Zagreb L 33-80 [Basic Geological Map of SFRY 1:100000, Geology of the Zagreb sheet - in Croatian].- Inst. geol. istraž., Zagreb (1972), Savezni geološki zavod, Beograd, $81 \mathrm{p}$.

TOMLJENOVIĆ, B., CSONTOS, L., MÁRTON, E. \& MÁRTON, P. (2008): Tectonic evolution of the northwestern Internal Dinarides as constrained by structures and rotation of Medvednica Mountains, North Croatia.- In: FÜGENSCHUH, B., FROITZHEIM, N. \& SIEGESMUND, S. (eds.): Tectonic Aspects of the Alpine-Dinaride-Carpathian System, 298. Geological Society, Special Publications, London, 145-167. doi: 10.1144/SP298.8

VALCHEV, B. (2003): On the potential of Small Benthic Foraminifera as Palaeoecological Indicators: Recent Advances.-Ann. UMG, 46, Part I, Geol. and Geophys., 51-56.

VAN DER ZWAAN, G.J., DUJINSTEE, I.A.P., DEN DULK, M., ERNST, S.R., JANNINK, N.T. \& KOUWENHOVEN, T.J. (1999): Benthic foraminiferes: proxies or problems? A review of palaeoecological concepts.- Earth Scien. Rev., 46, 213-236.

VAN DER ZWAAN, G.J., JORISSEN, F.J. \& DE STIGTER, H.C. (1990): The depth dependency of planktonic/benthic foraminiferal ratios: constrains and applications.Mar. Geol., 95, 1-16. doi: 10.1016/0025-3227(90)90016-D

VAN HINSBERGEN, D.J.J., KOUWENHOVEN, T.J. \& VAN DER ZWAAN, G.J. (2005): Palaeobathymetry in the backstripping procedure: Correction for oxygenation effects on depth estimates.- Palaeogeogr. Palaeoclimatol. Palaeoecol., 221, 245-265.

VELLA, P. (1962): Determining Depths of New Zealand Tertiary Seas.- Tuatara, 10, 19-39. 